\title{
Studies on the Stability of Fried Plantain Chips
}

\author{
M. A. Gonzalez, E. Draz Negrón, and A. R. Sandoval
}

\section{INTRODUCTION}

Plantain chips are prepared by deep-fat frying thin plantain slices (1).2 The shelf-life and acceptability of this snack is largely dependent on the type of fat or oil used for frying. In the deep-fat frying process, the fats or oils are subjected to high temperature, which renders them susceptible to oxidative rancidity. To increase the shelf-life of final products the use of highly hydrogenated shortening is desirable. However, these fats are expensive and usually do not impart to the fried products the rich flavor provided by other fats and oils, such as lard or corn oil.

Consumer preference and processing costs are the main factors which determine which fat or oil is to be used for the deep-fat frying of plantain chips. In order to find and recommend to the local processors which of the available commercial fats or oils should be used, a study was conducted to determine the effect of the type of fat used on the flavor, color, and stability of plantain chips.

\section{EXPERIMENTAL PROCEDURE}

\section{PROCESSING METHOD USTD}

Plantain chips were prepared following the method developed in this Laboratory by Cancel et al. (1).

Plantains were peeled by hand and sliced into 1/16-inch thickness with a standard rotary cutter. An electric deep-fat fryer, thermostatically controlled, having a capacity of 15 pounds of fat or oil, was used for frying. The fryer was provided with an indicating thermometer.

For frying, 15 pounds of the fresh fat or oil under study was heated in the kettle to $370^{\circ} \mathrm{F}$. Then a stainless-steel wire basket containing approximately $1 / 2$ pound of plantain slices was lowered into the hot fat, and the slices were fried for 3 minutes. The slices were stirred with a stainless-steel wire fork to prevent sticking and assure uniform temperature throughout the batch. In all the experiments the fats and oils were heated for the same length of time, and equal quantities of plantains were processed in each lot of fat or oil.

The plantain chips were drained on absorbent paper. After the excess fat

1 Associate Food Technologist, Assistant Chemist, and former Research Assistant, respectively, Agricultural Experiment Station, Mayagüez Campus, University of Puerto Rico, Rio Piedras, P.R.

2 Italic numbers in parentheses refer to Literature Cited, p. 74. 
or oil was drained off, the plantain chips were mixed and divided into two equal portions. To one portion approximately 2 percent by weight of pulverized salt with antioxidant was added, while to the other portion only plain pulverized salt was added.

Samples from both portions were used to determine the stability of the product through chemical analysis and organoleptic tests.

\section{STABIIITY DFTERMINATION}

The evaluation of the stability of the plantain chips was performed using the Schaal Oven Method (2). Samples of plantain chips of about $50 \mathrm{~g}$. were placed in an ordinary Griffin low-form beaker of 250-ml. capacity with lip, covered with a 3-inch watchglass. The samples were placed in the Schaal Oven at $63.5^{\circ} \mathrm{C}$., and smelled daily for the detection of rancid odor. Rancidity was confirmed by estimating the peroxide development during the oven test. Peroxide formation in the test sample was determined by using the extraction method described by Joyner and McIntyre (2). The fat was extracted in a mixture of 60-percent glacial acetic acid and 40-percent chloroform. The extracts were combined to $200-\mathrm{ml}$ volume. An aliquot of $25 \mathrm{ml}$. was used to determine the peroxide value, using the method of Wheeler (S).

The peroxide content of the fats or oils in the plantain chips was determined before the samples were placed in the oven and throughout the duration of the test at intervals from 2 to 4 days. A curve was plotted showing the course of the peroxide formation during this test.

\section{MOISTURT DETERMTNATION}

About $10 \mathrm{~g}$. of the chips were accurately weighed in a previously dried and weighed aluminum dish provided with cover. The sample was dried to constant weight in a vacuum oven at $60^{\circ}$ to $65^{\circ} \mathrm{C}$.

\section{FAT DETFRMINATION}

The fat was extracted from a previously dried and ground sample of 1.5 to $2.0 \mathrm{~g}$ with ether in a Soxhlet-type extractor during 18 to 20 hours. The ether extract was evaporated and the residue dried for 30 minutes in the oven at $95^{\circ}-100^{\circ} \mathrm{C}$., cooled in a desiccator, and weighed.

\section{ORGANOLEPTIC APPRAISALS}

A panel of experienced tasters was used to judge the differences in general appearance, color, and flavor of the plantain chips fried in different fats and oils. The tasters were seated in air-conditioned tasting booths under red light in order to mask the natural color of the plantain chips while scoring for flavor. Flavor-acceptance tests were conducted under the conditions 
described above by using the rank-order test (4). Judges were presented all samples identified by code simultaneously. They were asked to rank all samples according to flavor quality.

General appearance and color was scored under natural light. A simplified method of the Kramer (5) taste-panel test was used to determine the sample having the best appearance and color. The samples were presented to the panelists in a previously arranged order. The tasters evaluated each on a specific scale of 5 points, where +2 , indicated very acceptable; +1 , probably acceptable; 0 , questionable; -1 , slightly acceptable; -2 , not acceptable.

\section{EXPERIMENTAL RESULTS}

\section{STABILITY OF FATS AND OILS}

In the determination of the stability of fatty products by the Schaal Oven Method the principal limitation of the test is the personal evaluation of the

TABue 1.-Stability of lard and vegetable oils as determined by the Schaal oven method ${ }^{1}$

\begin{tabular}{l|c|c}
\hline \multicolumn{1}{c|}{ Type of fat or oil used } & $\begin{array}{c}\text { Schaal oven days } \\
\text { at } 63.5^{\circ} \mathrm{C} .\end{array}$ & $\begin{array}{c}\text { Peroxide values at point of } \\
\text { organoleptic rancidity } \\
\text { (meq. of peroxide/kg. } \\
\text { of oil) }\end{array}$ \\
\hline Lard & 8 & 21 \\
Cottonseed oil & 8 & 77 \\
Corn oil & 9 & 30 \\
Hydrogenated vegetable shortening & 68 & 67 \\
Mixture: 40-percent lard and 60-percent \\
hydrogenated vegetable shortening
\end{tabular}

1 Each figure represents the computed mean of 3 replicates.

point at which organoleptic rancidity can be detected. In order to train the tasters to determine by organoleptic test the point at which organoleptic rancidity occurs, samples of the commercial fats and oils were placed in the Schaal Oven at $63.5^{\circ} \mathrm{C}$. and smelled daily until the rancid odor was noticeable. Concurrently the peroxide content of the fats and oils under study was determined before samples were placed in the oven, and during the course of the oven test at intervals from 2 to 4 days.

Table 1 shows the Schaal Oven-days and peroxide content at which the fats and oils displayed rancidity.

Organoleptic rancidity was detected at a fairly uniform peroxide concentration for each fat or oil under study. This finding is in accord with the statement of Joyner et al. (2) which indicates that any kind of fat or oil that has 
been subjected to the same processing conditions will nearly always develop organoleptic rancidity at fairly uniform peroxide values.

\section{STABILITI TEST OF PLANTAIN CHIPS}

Table 2, shows the results obtained when using different fats and oils for deep-fat frying of plantain chips. These results indicate that the longest shelf-life of plantain chips is obtained when the plantain slices are fried in hydrogenated vegetable shortening. Plantain slices fried in a mixture of 60-percent hydrogenated vegetable shortening and 40-percent lard, ranked second in shelf-life.

During the course of this work we have observed that the change in color of the plantain chips could be used to determine the point at which organo-

TaBle 2.-Effect of using different fats and oils upon the stability of the plantain chips

\begin{tabular}{l|c|c}
\hline \multicolumn{1}{c|}{ Frying medium } & \multicolumn{2}{|c}{ Storage life of plantain chips at 63.5 $\mathrm{c}}$. \\
\cline { 2 - 3 } & Days & $\begin{array}{c}\text { Peroxide value at point of } \\
\text { taste rarcidity (meg of } \\
\text { peroxide/kg. of oil) }\end{array}$ \\
\hline Lard & 8 & 24 \\
Cottonseed oil & 7 & 29 \\
Corn oil & 8 & 30 \\
Hydrogenated vegetable shortening & 68 & 58 \\
Mixture: 40-percent lard and 60-percent & 40 & 38 \\
$\quad$ hydrogenated vegetable shortening & & \\
\hline
\end{tabular}

leptic rancidity occurs. At the end of the rancidity-induction period, the typical golden-yellow color of plantain chips turns very light. This sudden change in color occurs in a period of about 24 hours after the rancidityinduction period.

It was found that the shelf-life in terms of rancidity development was not affected by differences in the fat and moisture content of the chips, since irrespective of the fat used, the slices absorbed about 32-percent fat and the moisture content was always around 1 percent.

\section{APPLICATION OF ANTIOXIDANTS AFTER THE DEFP-FAT FRYING PROCESS}

It is common practice to add an antioxidant to the fats or oils prior to frying, with the intention that the fat or oil absorbed by the food in the frying process contains some of the antioxidants, and can thus be stabilized. It has been found that the high temperatures normally used in the deep-fat frying process decompose or volatilize the antioxidants, thus reducing their 
effect (6). In order to increase the shelf-life of deep-fat fried foods, it has been found necessary to add the antioxidants after the frying operation (7).

Antioxidants were added to the fried plantain chips to determine how their shelf-life was affected. A mixture of salt and antioxidants such as propylene glycol, butylated hydroxyanisole, propyl gallate, and citric acid was incorporated into the chips during the salting process. The results obtained with the use of plain salt and the mixture of salt and antioxidant for seasoning the plantain chips are shown in table 3. As indicated by these results the antioxidants added after the deep-fat frying process definitely increase the shelf-life of the plantain chips. These results are obtained irrespective of the frying medium used.

TABLE 3.-Effect of using antioxidant salt upon the stability of plantain chips

\begin{tabular}{l|c|c}
\hline \multicolumn{1}{c|}{ Frying medium } & \multicolumn{2}{|c}{ Storage life of plantain chips at 63.5 C. (days) } \\
\cline { 2 - 3 } & Regular salt & $\begin{array}{c}\text { Mixture of salt }+ \\
\text { antioxidant }\end{array}$ \\
\hline Lard & 8 & 12 \\
Cottonseed oil & 7 & 9 \\
Corn oil & 8 & 14 \\
Hydrogenated vegetable shortening & 68 & 85 \\
Mixture: 40-percent lard and 60-percent & 40 & 67 \\
hydrogenated vegetable shortening & & \\
\hline
\end{tabular}

1 Each figure represents the computed mean of 3 replicates.

EFFECT OF FAT OR OIL USED IN FRYING ON PRODUCT ACCEPTANCE

Organoleptic appraisal tests were used to determine how the general acceptance of the plantain chips is affected by the use of different fats or oils for frying.

The Kramer Rank-Order Test (4) was used to determine how the several samples differed on the basis of flavor; in this test no particular sample was selected as reference. The results of this test are indicated in the tabulation that follows:

\begin{tabular}{|c|c|c|c|c|c|}
\hline Frying medium & Corn oil & Lard & Collonseed oil & $\begin{array}{l}\text { Mixlure of } \\
\text { Go-percont } \\
\text { hydrogenaled } \\
\text { oegeloblo } \\
\text { shorleming, and } \\
\text { 40-percent lard }\end{array}$ & $\begin{array}{l}\text { Bydrogenaled } \\
\text { oggeleble } \\
\text { shorlensing }\end{array}$ \\
\hline
\end{tabular}

Rank sum (15 repli-

30

31

49

51

64

cates)

Probability range at

5-percent $\mathbf{P}(32-58)$ 
The range of values for significant difference at 5-percent $P$ is from 32 to 58. Since the rank sums are lower than 32 and higher than 58 , there is a significant difference in acceptance among samples. The samples fried in corn oil and lard were the best, while those fried in hydrogenated vegetable shortening were the least acceptable.

The rank of the samples fried in cottonseed oil and the mixture of hydrogenated vegetable shortening and lard is between $32-58$. To determine whether any further real difference existed between the flavor of both samples, they were ranked. The results obtained indicated that there was no real difference in the rank sum of these samples. The rank sum was between the corresponding entries for two treatments and 15 replicates. It can be concluded that there is no difference in the flavor of plantain chips deep-fat fried in cottonseed oil and the mixture of 60-percent hydrogenated vegetable oil and 40-percent lard.

A simplified variable test $(5)$ was used to determine the samples having the most desirable general appearance and color. The results of these tests indicate that corn oil and lard impart the most desirable appearance and color to the plantain chips. The mixture of hydrogenated vegetable shortening-lard and cottonseed oil form an intermediate group. Hydrogenated vegetable shortening imparted the least desirable appearance and color to the plantain ships.

\section{DISCUSSION AND CONCLUSION}

A summary of the results obtained in these experiments are indicated in the tabulation that follows:

Planlain ckips deep-fal-fried in-

Corn oil

Lard

Mixture of 60-percent hydrogenated vegetable shortening and 40-percent lard

Cottonseed oil

Hydrogenated vegetable shortening
Ranking of planlain chips is related to:

$\begin{array}{cc}\text { Product acceptance } & \text { Shelf-lifc } \\ 1 & 4 \\ 2 & 4 \\ 3 & 2 \\ 4 & \\ 5 & 4 \\ & \end{array}$

These results show that the longest shelf-life in plantain chips is obtained when they are fried in a fully hydrogenated vegetable shortening. Plantain slices fried in a mixture of 60 -percent hydrogenated vegetable shortening and 40-percent lard rank second in shelf-life. The stability of the same product is very low when fried in corn oil, cottonseed oil and lard.

The organoleptic tests indicate that corn oil and lard impart the most desirable color and flavor to the plantain chips. The product obtained when the mixture of 60-percent hydrogenated vegetable shortening and 40-percent lard is used as the frying medium rank third in general acceptance, 
while the product fried in cottonseed oil and fully hydrogenated vegetable shortening is the least acceptable.

Consumer preference, processing costs, and keeping-quality are the main factors which determine which fat or oil is to be used commercially for deep-fat frying plantain chips in Puerto Rico. From this study it appears that the frying medium for plantain chips that meets these requirements is the mixture of 60-percent hydrogenated vegetable shortening and 40-percent lard. The product fried by this method, as indicated in the above tabulation, ranked second in shelf-life and in general acceptance, and was classified very close to the products fried in corn oil and lard. This frying medium imparts to the plantain chips the high-stability characteristics of the hydrogenated vegetable shortening and the rich flavor of lard. Also, lard is cheaper than the other fats and oils studied.

The use of highly hydrogenated vegetable shortening alone is not recommended for the deep-fat frying of plantain chips, because, although the end product has very good stability, it lacks rich flavor, good color, and an acceptable general appearance. The production costs are also higher when this shortening is used alone for deep-fat frying.

For the production of a high-quality product of rich flavor, good color, and highly acceptable general appearance, that is consumed in a period from 15 to 20 days the best frying media are corn oil and lard.

The use of salt with antioxidant is recommended for seasoning the plantain chips. The shelf-life of the end-product is increased, irrespective of the fat or oil used for deep-fat frying.

\section{SUMMARY}

The stability of plantain chips has been studied. Five commercial brands of fats and oils, including a mixture of hydrogenated vegetable shortening and lard, were used in the deep-fat frying of plantain chips. The stability of the end product was determined by chemical analysis and organoleptic tests.

The results obtained from these experiments indicate that the plantain chips fried in hydrogenated vegetable shortening have the highest stability, but lack the rich flavor, good color, and an acceptable general appearance.

The plantain chips deep-fat fried in corn oil, lard, and cottonseed oil, although they have very short shelf-life, have a rich flavor, good color, and a highly acceptable general appearance.

The mixture of hydrogenated vegetable shortening and lard produces an intermediate group. The plantain chips fried in this medium have the high stability due to the hydrogenated vegetable shortening and the rich flavor and color that the lard imparts.

The shelf-life of the plantain chips is increased when a mixture of anti- 
oxidants and salt is used for seasoning. This effect is obtained irrespective of the fat or oil used for deep-fat frying.

\section{RESUMEN}

Se ha estudiado la estabilidad de las grasas en las hojuelas de plátano usando el método de Schaal, en el cual se utiliza un horno con circulación de aire a $63.5^{\circ} \mathrm{C}$. y tomando el contenido de peróxido en las grasas, como indice de rancidez. Para determinar la aceptación general de las hojuelas de plátano se hicieron pruebas organolépticas de cuatro grasas comerciales y de una mezcla de manteca de cerdo y aceite vegetal hidrogenado para freir las rebanadas de plátanos a una temperatura de $370^{\circ} \mathrm{C}$.

Los resultados de las determinaciones de estabilidad y de las pruebas organolépticas indican, que cuando se usa el aceite vegetal hidrogenado se obtiene un producto final de larga duración bajo almacenamiento, pero éste es de baja calidad, y adquiere un sabor y un color poco aceptables. Por otro lado, cuando se usa aceite de maíz y manteca de cerdo para freir, el producto final tiene un sabor muy agradable y un buen color, aunque en este caso las hojuelas suelen ponerse rancias más pronto.

Hasta el presente, el mejor medio para freir las hojuelas de plátano es una mezcla de un 60 por ciento de aceite vegetal hidrogenado y un 40 por ciento de manteca de cerdo. El producto final posee la estabilidad del aceite vegetal hidrogenado y el buen sabor y color que le imparte la manteca de cerdo.

El resultado de las pruebas cuando se usaron y evaluaron los antioxidantes para mejorar las cualidades de almacenamiento de las hojuelas, indica que los antioxidantes son muy efectivos cuando se añaden después de freir. Su aplicación surte mejores efectos cuando se usa una mezcla de antioxidantes y sal para condimentar las hojuelas de plátanos.

\section{LITERATURE CITED}

1. Cancel, L. E., Gonź́lez, M. A., and Sánchez-Nieva, F., Elaboración del Platanutre, Publ. Misc. 6, L. T. A., Est. Expt. Agr., Univ. P. R., 1962.

2. Joyner, N. T. and McIntyre, J. E., The Oven Test as an Index of Keeping Quality, Oil and Soap 16: 184-6, 1938.

3. Mehlenbacher, V. C., The Analysis of Fats and Oils, Wheeler Method, 225-6, Garrard Press Publishers, Champaing, Ill., 1960.

4. Kramer, A., and Twigg, B. A., Fundamentals of Quality Control for the Food Industry, the Avi Publishing Co., Inc., Westport, Conn., 130-1, 1962.

5. Kramer, A., and Ditman, L. P., A Simplified Variable Taste Panel Method for Detecting Flavor Changes in Vegetables Treated With Pesticides, Food Technol. 10 (3): 155-9, 1956.

6. Sair, L., Hall, L. A., The Use of Antioxidants in Deep-Fat Frying, Food Technol. 6: $69-73,1951$.

7. Jain, N. L., Nair, J., Siddappa, M., and Girdhari, Lal., Studies to Improve the Keeping Quality of Fried Salted Bananas Chips, Food Sci. (Mysore) 11: 335, 1962. 